\title{
SCLEROTINIA SCLEROTIORUM AND MOWING INDEPENDENTLY REDUCE CALIFORNIAN THISTLE IN A SHEEP PASTURE
}

\author{
G.A. HURRELL and G.W. BOURDÔT \\ AgResearch, New Zealand Pastoral Agriculture Research Institute Ltd, \\ P O Box 60, Lincoln
}

\begin{abstract}
An experiment was conducted in a sheep-grazed pasture in Canterbury to test the hypothesis that control of Californian thistle by Sclerotinia sclerotiorum, applied as a mycoherbicide, is limited because the thistle roots escape from the fungus by rapid growth. Replicated field plots were either not treated or treated with the mycoherbicide in spring 1993 and again in spring 1994. The thistles were then either mown on three occasions in each of the summers to limit root growth, or left to develop normally. Both the S. sclerotiorum mycoherbicide and mowing reduced the thistle's root-bud population, as measured by the shoot population emerging in the summers following treatment, but these effects were not synergistic, providing no support for the hypothesis.
\end{abstract}

Keywords: mycoherbicide, Sclerotinia sclerotiorum, Californian thistle, Cirsium arvense

\section{INTRODUCTION}

Californian thistle (Cirsium arvense L. Scop.) is a widely distributed weed of grazed pastures in New Zealand (Bascand and Jowett 1982) which is not well controlled with herbicides (Meeklah and Mitchell 1984; Hartley et al. 1984) nor readily controlled under normal grazing pressure (Hartley and James 1979; Hartley et al. 1984). A commonly employed control is mowing during the summer months. Frequent defoliation by mowing and/or hard grazing can result in significant reductions in populations of the thistle and economic improvements in pasture productivity and quality (Hartley and James 1979; Hartley and Thomson 1982; Mitchell and Abernethy 1993, 1995).

The pathogenic fungus Sclerotinia sclerotiorum, when formulated as a mycoherbicide, can also give significant reductions in shoot and root-bud populations when applied to the thistle foliage in spring (Bourdôt et al. 1993, 1995) with no detrimental effects on pasture grasses or clovers (Hurrell and Bourdôt 1993). An hypothesis advanced by Bourdôt et al. (1993) to explain why complete destruction of the thistle root system does not result, despite the invasion of the fungus into the roots, is that the roots escape from the fungus by rapid growth over the summer. Summer defoliation of the thistle by mowing or grazing is detrimental to population growth (Mitchell and Abernethy 1993, 1995). This is apparently because the catastrophic reduction in photosynthetic capacity associated with regular defoliation causes a concomitant reduction in root growth rate, which in turn results in reduced numbers of root-buds and shoots in the population. We considered then, that mowing the thistle after application of $S$. sclerotiorum, would be a suitable treatment to test the hypothesis.

This paper reports on a single experiment conducted over two consecutive growing seasons in a Canterbury sheep pasture, in which the interacting effects of mowing and $S$. sclerotiorum were investigated. 


\section{METHODS}

The experiment was conducted in a perennial ryegrass (Lolium perenne L.) and white clover (Trifolium repens L.) pasture, at the AgResearch Research Farm at Templeton. The field was rotationally grazed by sheep and flood-irrigated in summer. The pasture contained a dense and uniformly distributed population of Californian thistle.

There were four treatments; (1) no S. sclerotiorum and no mowing, (2) no S. sclerotiorum plus mowing, (3) S. sclerotiorum and no mowing, (4) S. sclerotiorum plus mowing. The mycoherbicide was a dried mycelium-on-wheat preparation of a wild strain of $S$. sclerotiorum described by Bourdôt et al. (1993). The mycoherbicide treatment was applied with a granule applicator at $50 \mathrm{~g} / \mathrm{m}^{2}$ to pasture containing vegetative rosettes of the thistle on 24 October 1993. The mowing treatment was imposed with a petrol-powered Weedeater equipped with a disc-type blade, which severed the thistle shoots at ground level. This operation was repeated on three occasions during the summer of 1993/4 (22 December, 14 January and 14 March). These mycoherbicide and mowing treatments were re-applied to the same plots during the summer of 1994/5 (1 November 1994 and 20 December, 7 February and 6 March respectively).

The treatments were arranged in a split-plot design, with the mycoherbicide as the main-plot treatment and mowing as the sub-plot treatment, replicated eight times within the confines of a $10 \mathrm{~m}$ wide irrigation border. The plots were $5 \mathrm{~m}$ wide and 8 $\mathrm{m}$ long.

The effects of the treatments were measured by enumerating the adventitious shoots that emerged in the spring after treatment in eight $0.25 \mathrm{~m}^{2}$ quadrats randomly positioned within each plot. This was done for the first year of treatment on 7 December 1994 and for the second year of treatment on 15 December 1995 . The counts on 7 December 1994 were taken before any mortalities occurred as a result of the second application of the mycoherbicide, and before the mowing treatment was reimposed. Shoot data were transformed to square-root values and subjected to an analysis of variance.

The following meteorological data were obtained from the nearby Broadfields station, $7 \mathrm{~km}$ from the experimental site, for the duration of the experiment: total monthly rainfall, monthly mean maximum daily temperature, rain days per month and dew days per month. An estimate of the number of days per month during which free moisture occurred on foliage (leaf wet-days) was calculated as the number of days per month where wetness occurred as either dew or rain.

\section{RESULTS AND DISCUSSION}

In December 1994, 13 months after the mycoherbicide was applied for the first time, there were 13.2 shoots $/ \mathrm{m}^{2}$ on the untreated plots (Table 1). On the mowed only plots, there were 3.5 shoots $/ \mathrm{m}^{2}$, a $73 \%$ reduction due to the mowing $(\mathrm{P}<0.01)$. Treatment with $S$. sclerotiorum alone resulted in a shoot density of 6.6 shoots $/ \mathrm{m}^{2}$, and when mowing was imposed as well, the result was a population density of 2.3 shoots/ $\mathrm{m}^{2}$, a $65 \%$ reduction compared to $S$. sclerotiorum alone. The interaction was not significant, the mowing and $S$. sclerotiorum treatments acting independently in their effects on the thistle population.

The results a year later in December 1995, after the treatments had been re-applied to the plots, were similar to those from the first year (Table 1). There were now 21.9 shoots $/ \mathrm{m}^{2}$ on the untreated plots and 3.3 shoots $/ \mathrm{m}^{2}$ on the mown-only plots, an $85 \%$ reduction due to the mowing $(\mathrm{P}<0.01)$. Treatment with $S$. sclerotiorum alone resulted in a shoot density of 17.9 shoots $/ \mathrm{m}^{2}$, and when mowing was imposed as well, the result was a population density of 1.8 shoots $/ \mathrm{m}^{2}$, a $90 \%$ reduction compared toS. sclerotiorum alone. Again the interaction was not significant.

This experiment was conducted to test the hypothesis that destruction of the regenerative roots of Californian thistle by $S$. sclerotiorum, is limited by the root system's ability to grow more rapidly than the fungus can spread through it. Since there was no interaction between the effects of the mowing, which would have slowed 
root growth, and the effects of $S$. sclerotiorum, the experiment has provided no evidence in support of the hypothesis. Californian thistle roots apparently do not escape from $S$. sclerotiorum by growing more quickly than the fungus can spread through the root tissue. An alternative explanation for the lack of complete destruction of roots in treated thistle populations (Bourdôt et al. 1995) is that a population's root system is comprised of many separate root systems, on separate plants, some of which do not become infected following treatment with the fungus. This may be because they did not have aerial shoots at the time of application of the fungus, or that viable sections of the root system of infected plants become detached before the fungus reaches them, thereby continuing independent growth free of any effect of the fungus.

TABLE 1: Density of Californian thistle shoots $\left(\mathrm{No} . / \mathrm{m}^{2}\right)$ emerging in a sheep pasture in December 1994 and in December 1995, as influenced by mowing and $S$. sclerotiorum treatment in the preceding year(s). Data given as means of square root transformed values (backtransformed means in parentheses). $\operatorname{LSD}(5 \%)$ values are for [a] horizontal comparisons within a year, and [b] for any other comparison of treatment means with a year.

\begin{tabular}{lllll}
\hline & \multicolumn{2}{c}{1994} & \multicolumn{2}{c}{1995} \\
& Not mown & Mown & Not mown & Mown \\
\hline No S. sclerotiorum & $3.64(13.2)$ & $1.86(3.5)$ & $4.68(21.9)$ & $1.81(3.3)$ \\
S. sclerotiorum & $2.56(6.6)$ & $1.52(2.3)$ & $4.23(17.9)$ & $1.33(1.8)$ \\
LSD(5\%) [a] & \multicolumn{2}{c}{0.72} & \multicolumn{2}{c}{0.70} \\
LSD(5\%) [b] & \multicolumn{2}{c}{0.81} & \multicolumn{2}{c}{0.81} \\
\hline
\end{tabular}

The effect of the S. sclerotiorum treatment alone on the shoot population emerging after treatment in 1993 (a 51\% reduction compared to control) was considerably greater than the effect following the 1994 application (an 18\% reduction) (Table 1). This was possibly due to the lower moisture conditions in the months after application in 1994 (Fig. 1). While air temperature was within the range allowing active growth of the fungus in both seasons, rainfall and the number of days during which treated foliage was wet due to rain or dew (Leaf wet-days), was lower in November and December in 1994 than in 1993 (Fig. 1).
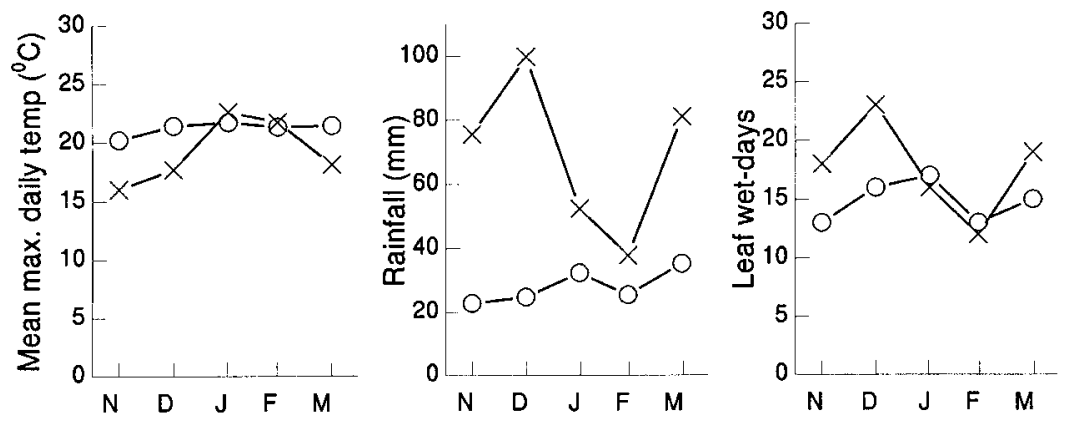

Month

FIGURE 1: Mean maximum daily temperature, monthly rainfall and leaf wetdays for the months of November through to March for the two years when treatments were imposed (1993/4 [x], 1994/5 [o] ). 
Repeated defoliation of Californian thistle by intense grazing of regrowth following mowing has proved to be a powerful tool for bringing about population decline in pastures in Otago (Mitchell and Abernethy 1993, 1995). Our results also support this, and indicate that mowing on three occasions during the summer in Canterbury can cause a decline in a Californian thistle population (Table 1). By contrast, S. sclerotiorum applied for a second time in 1994, apparently did not cause sufficient mortality to allow the population decline resulting from the first application in 1993, to continue. The results indicate that the effects of mowing are probably independent of weather conditions whilst the effectiveness of applications of S. sclerotiorum may be very dependent on weather conditions, particularly those determining leaf wetness.

\section{ACKNOWLEDGEMENTS}

The authors thank David Saville for his helpful advice on experimental design and data presentation.

\section{REFERENCES}

Bascand, L. D. and Jowett, G. H., 1982. Scrubweed cover of South Island agricultural and pastoral land. 2. Plant distribution and managerial problem status. N.Z. J. Exp. Agr. 10: 455-492.

Bourdôt, G. W., Harvey, I. C., Hurrell, G. A. and Alexander, R. T., 1993. An experimental mycoherbicide utilising Sclerotinia sclerotiorum controls pasture populations of Cirsium arvense in Canterbury. Proc. 46th N.Z. Plant Prot. Conf.: 251-256.

Bourdôt, G. W., Harvey, I. C., Hurrell, G. A. and Saville, D. J., 1995. Demographic and biomass production consequences of inundative treatment of Cirsium arvense with Sclerotinia sclerotiorum. Biocont. Sci. Tech. 5: 11-25.

Hartley, M. J. and James, T. K., 1979. Cost benefit of selective control of Californian thistle in pasture. Proc. 32nd N.Z. Weed and Pest Control Conf.: 245-249.

Hartley, M. J., Lyttle, L. A. and Popay, A. I., 1984. Control of Californian thistle by grazing management. Proc. 37th N.Z. Weed and Pest Control Conf.: 24-27.

Hartley, M. J. and Thomson, N. A., 1982. Effect and control of Californian thistle in dairy pasture. Proc. N.Z. Grasslands Assoc. Conf. 43: 104-107.

Hurrell, G. A. and Bourdôt, G. W., 1993. Pasture grasses and white clover unaffected by an inundative application of Sclerotinia sclerotiorum. Proc. 46th N.Z. Plant Prot. Conf: : 257-260.

Meeklah, F. A. and Mitchell, R. B., 1984. Evaluation of herbicides for control of Californian thistle. Proc. 37th N.Z. Weed and Pest Control Conf.: 20-23.

Mitchell, R. B. and Abernethy, R. J., 1993. Integrated management of Californian thistle in pasture. Proc. 46th N.Z. Plant Prot. Conf.: 278-281.

Mitchell, R. B. and Abernethy, R. J., 1995. The effect of topping and repeat grazings on Californian thistle and pasture production. Proc. 48th N.Z. Plant Prot. Conf: 189-193. 